\title{
KONTRIBUSI EKSPEKTASI KARIR, MOTIVASI BERPRESTASI, KOMPETENSI PEDAGOGIK GURU, DAN SARANA PRASARANA SEKOLAH TERHADAP HASIL BELAJAR PRAKTIKUM SISWA KELAS X JURUSAN TATA BOGA DI SMK NEGERI 2 SINGARAJA
}

\author{
Ni Putu Triastuti Kawisari, I Nyoman Natajaya, I Gst Ketut Arya Sunu \\ Program Studi Administrasi Pendidikan, Program Pascasarjana \\ Universitas Pendidikan Ganesha \\ Singaraja, Indonesia
}

e-mail: \{triastuti.kawisari,nyoman.natajaya, Arya Sunu\}@pasca.undiksha.ac.id.

\begin{abstract}
Abstrak
Penelitian ini bertujuan untuk mengetahui kontribusi ekspektasi karir, motivasi berprestasi, kompetensi pedagogik guru, dan sarana prasarana sekolah terhadap hasil belajar praktikum siswa kelas $X$ Jurusan Tata Boga Di SMK Negeri 2 Singaraja. Penelitian ini adalah penelitian "ex-post facto" dengan besar sampel 103 orang. Data dikumpulkan dengan kuesioner dan dokumen. Analisis data dilakukan dengan teknik regresi sederhana, regresi ganda, dan korelasi parsial. Hasil penelitian menunjukkan bahwa: 1) terdapat kontribusi yang signifikan ekspektasi karir terhadap hasil belajar Praktikum pada siswa kelas X Jurusan Tata Boga di SMK Negeri 2 Singaraja dengan koefisien korelasi sebesar 0,763, korelasi parsial 0,565 dan sumbangan efektifnya sebesar $36,42 \%$. 2) terdapatkontribusi yang signifikan motivasi berprestasi terhadap hasil belajar Praktikum pada siswa kelas X Jurusan Tata Boga di SMK Negeri 2 Singaraja. dengan koefisien korelasi sebesar 0,475, korelasi parsial 0,206 dan sumbangan efektifnya sebesar $5,97 \%$. 3) terdapatkontribusi yang signifikan kompetensi pedagogik terhadap hasil belajar Praktikum pada siswa kelas X Jurusan Tata Boga di SMK Negeri 2 Singaraja dengan koefisien korelasi sebesar 0,672 , korelasi parsial 0,391 dan sumbangan efektifnya sebesar $19,38 \%$. 4) terdapatkontribusi yang signifikan sarana prasarana sekolah terhadap hasil belajar Praktikum pada siswa kelas X Jurusan Tata Boga di SMK Negeri 2 Singaraja dengan koefisien korelasi sebesar 0,663, korelasi parsial 0,211 dan sumbangan efektifnya sebesar 10,39\%.5) secara bersama-sama, terdapat kontribusi yang signifikan ekspektasi karir, motivasi berprestasi, kompetensi pedagogik, dan sarana prasarana sekolah terhadap hasil belajar Praktikum pada siswa kelas X Jurusan Tata Boga di SMK Negeri 2 Singaraja dengan koefisien korelasi ganda sebesar 0,849 dan kontribusinya sebesar $72,16 \%$ terhadap hasil belajar Praktikum siswa kelas X Jurusan Tata Boga di SMK Negeri 2 Singaraja.
\end{abstract}

Kata kunci: ekspektasi karir, motivasi berprestasi, kompetensi pedagogik, sarana prasarana sekolah, hasil belajar Praktikum

\begin{abstract}
This study aims to determine the contribution of career expectations, achievement motivation, teacher pedagogic competence, and school infrastructure facilities to the results of class $X$ students studying Department of Culinary In SMK Negeri 2 Singaraja. This study is an "ex-post facto" study with a sample size of 103 people. Data were collected with questionnaires and documents. Data analysis was performed by simple regression, multiple regression, and partial correlation. The result of the research shows that: 1) there is a significant contribution career expectation toward the result of Practicum study on the $\mathrm{X}$ class students of Department of Culinary at SMK Negeri 2 Singaraja with correlation coefficient 0,763 , partial correlation of 0,565 and effective contribution equal to $36,42 \%$. 2) there is a significant contribution achievement motivation toward result of Practicum study at $X$ class student of Department of Culinary at SMK Negeri 2 Singaraja. with a correlation coefficient of 0.475 , partial correlation of 0,206 and an effective contribution of $5.97 \%$. 3) there is significant contriubution pedagogic competence on Practicum learning outcomes in grade X students of Department of Culinary at SMK Negeri 2 Singaraja with correlation coefficient of 0.672 , partial correlation of 0,391 and effective contribution of $19.38 \%$. 4) there is significant contriubution school infrastructure and the result of Practicum study on X grade students of Department of Culinary at SMK Negeri 2 Singaraja with correlation coefficient of 0,663 , partial correlation of 0,211 and effective contribution equal to
\end{abstract}


$10,39 \% .5)$ collectively, there is a significant contribution between career expectation, achievement motivation, pedagogic competence, and school infrastructure facilities on the result of Practicum study on X grade students of Department of Culinary at SMK Negeri 2 Singaraja with double correlation coefficient equal to 0,849 and its contribution equal to $72,16 \%$ toward result of Practicum study of class $X$ student of Department of Culinary at SMK Negeri 2 Singaraja.

Keywords: career expectations, achievement motivation, pedagogical competence, school infrastructure, learning outcomes Practicum

\section{PENDAHULUAN}

Menurut UU RI No. 20 Tahun 2003, tujuan pendidikan Sekolah Menengah Kejuruan (SMK) adalah mempersiapkan peserta didik terutama bekerja dalam bidang tertentu, selanjutnya secara spesifik tujuan SMK yang terdapat dalam kurikulum 2004 adalah: 1) Menyiapkan siswa memasuki lapangan kerja serta mengembangkan sikap profesional, 2) menyiapkan siswa agar mampu memiliki karir, maupun berkompetisi dan mampu mengembangkan diri, 3) menyiapkan tenaga kerja menengah untuk mengisi kebutuhan dunia usaha dan dunia industri pada saat ini maupun pada saat yang akan datang, 4) menyiapkan tamatan agar menjadi warga negara yang produktif, adaptif, dan kreatif sesuai dengan Kurikulum 2004.

Berdasarkan tujuan SMK tersebut dapat dikatakan bahwa lulusan SMK diharapkan menguasai mata pelajaran lebih baik secara teori maupun secara praktek sehingga peserta didik dapat mandiri dengan penerapan ilmu yang diperolehnya dari sekolah sesuai dengan bidangnya masing-masing (Garis-Garis Besar Program Pendidikan, 2004).

Dalam meningkatkan kualitas lulusan SMK khususnya Tata Boga, ada banyak faktor yang mempengaruhinya, salah satunya adalah saran dan prasarana seperti laboratorium praktek, perpustakaan, serta alat-alat praktek. Jika standar tersebut belum terpenuhi para siswa tidak dapat melaksanakan praktek atau latihan untuk menerapkan ilmu yang telah diperolehnya dari guru. Untuk itu harus ada upaya dalam perbaikan fasilitas pada SMK terutama alat praktek di Laboratorium sekolah. Pihak sekolah diharapkan dapat mengembangkan serta memperluas akses dan kemudahan praktikum bagi siswa SMK.

Salah satu hal yang dapat mendukung hasil belajar siswa adalah ekspektasi karier. Ekspektasi karier adalah pengetahuan siswa tentang profesi apa yang ada atau dapat diciptakan dengan model pengetahuan dan keterampilan yang diperoleh dari sekolahnya. Ekspektasi atau harapan karir tersebut akan memberi dorongan yang kuat bagi siswa itu sendiri untuk lebih rajin belajar, sebab dengan mengetahui keadaan sebuah karir maka akan timbul keinginan untuk memperoleh karir tersebut. Keinginan inilah yang menjadi motor pengerak bagi siswa tersebut rajin belajar.

Faktor lain yang mempengaruhi hasil belajar adalah motivasi berprestasi siswa. Motivasi didefinisikan sebagai faktor penentu (determinan) dari perilaku individu dalam wujud kebutuhan (need), dorongan (drivers), dan desakan hati (inpuls), yang bekerja di bawah kesadaran. Jawaban atas pertanyaan mendasar seperti "mengapa individu melakukan suatu aktivitas" akan sampai pada pembahasan tentang motivasi. Motivasi sebagai faktor penentu perilaku bisa diduga dari perilaku yang ditimbulkannya.

Jadi motivasi merupakan daya dorong dalam diri seseorang untuk mengarahkan, melakukan serta menentukan tingkat usaha yang akan dilakukan. Motivasi adalah dorongan dasar yang menggerakkan seseorang bertingkah laku. Dorongan ini berada pada diri seseorang yang menggerakkan untuk melakukan sesuatu yang sesuai dengan dorongan dalam dirinya. Oleh karena itu, perbuatan seseorang yang didasarkan atas motivasi tertentu mengandung tema sesuai dengan motivasi yang mendasarinya.

Faktor berikutnya yang dapat mempengaruhi hasil belajar siswa adalah kompetensi pedagogik yang dimiliki oleh guru. Guru dalam pengelolaan pembelajaran dapat diartikan sebagai usaha guru untuk mengelola pembelajaran sehingga siswa dapat belajar dalam suasana yang menyenangkan (enjoyfull learning), serta beraktifitas tinggi baik mental, fisik, 
sosial, maupun emosinya, hal ini juga memiliki dampak secara langsung terhadap motivasi siswa, dan secara tidak langsung mempengaruhi hasil belajar yang dicapai oleh siswa.

Sarana dan prasarana pendidikan merupakan salah satu sumber daya yang penting dan utama dalam menunjang proses pembelajaran di sekolah, untuk itu perlu dilakukan peningkatan dalam pendayagunaan dan pengelolaannya, agar tujuan yang diharapkan dapat tercapai. Dalam khazanah peristilahan pendidikan sering disebut-sebut istilah sarana dan prasarana pendidikan. Kerap kali istilah itu digabung begitu saja menjadi sarana-prasarana pendidikan. Dalam bahasa Inggris sarana dan prasarana itu disebut dengan facility (facilities). Jadi, sarana dan prasarana pendidikan akan disebut educational facilities. Sebutan itu jika diadopsi ke dalam bahasa Indonesia akan menjadi fasilitas pendidikan. Fasilitas pendidikan artinya segala sesuatu (alat dan barang) yang memfasilitasi (memberikan kemudahan) dalam menyelenggarakan kegiatan pendidikan.

Erat terkait dengan sarana dan prasarana pendidikan itu, dalam daftar istilah pendidikan dikenal pula sebutan alat bantu pendidikan (teaching aids), yaitu segala macam peralatan yang dipakai guru untuk membantunya memudahkan melakukan kegiatan mengajar. Alat bantu pendidikan ini yang pas untuk disebut sebagai sarana pendidikan. Jadi, sarana pendidikan adalah segala macam peralatan yang digunakan guru untuk memudahkan penyampaian materi pelajaran. Jika dilihat dari sudut murid,sarana pendidikan adalah segala macam peralatan yang digunakan murid untuk memudahkan mempelajari mata pelajaran.

Pada umumnya orang mendefinisikan bahwa sarana pendidikan adalah segala macam alat yang digunakan secara langsung dalam proses pendidikan. Sementara prasarana pendidikan adalah segala macam alat yang tidak secara langsung digunakan dalam proses pendidikan. Jelasnya, disebut "langsung" itu terkait dengan penyampaian materi (mengajarkan materi pelajaran), atau mempelajari pelajaran. Papan tulis, misalnya, digunakan langsung ketika guru mengajar (di papan tulis itu guru menuliskan pelajaran). Meja murid tentu tidak digunakan murid untuk menulis pelajaran, melainkan untuk "alas" murid menuliskan pelajaran (yang dituliskan di buku tulis; buku tulis itulah yang digunakan langsung).

Perbedaan sarana pendidikan dan prasarana pendidikan adalah pada fungsi masingmasing, yaitu sarana pendidikan untuk "memudahkan penyampaian/ mempelajari materi pelajaran, "prasarana pendidikan untuk memudahkan penyelenggaraan pendidikan."

Mengingat pentingnya sarana prasarana dalam kegiatan pembelajaran, maka peserta didik, guru dan sekolah akan terkait secara langsung. Peserta didik akan lebih terbantu dengan dukungan sarana prasarana pembelajaran. Tidak semua peserta didik mempunyai tingkat kecerdasan yang bagus sehingga penggunaan sarana prasarana pembelajaran akan membantu peserta didik, khususnya yang memiliki kelemahan dalam mengikuti kegiatan pembelajaran. Bagi guru akan terbantu dengan dukungan fasilitas sarana prasarana. Kegiatan pembelajaran juga akan lebih variatif, menarik dan bermakna. Sedangkan sekolah berkewajiban sebagai pihak yang paling bertanggung jawab terhadap pengelolaan seluruh kegiatan yang diselenggarakan. Selain menyediakan, sekolah juga menjaga dan memelihara sarana prasarana yang telah dimiliki sarana prasarana yang perlu dalam Administrasi Pendidikan.

SMK Negeri 2 Singaraja dalam hal ini mutlak harus mempunyai sarana dan prasarana laboratorium praktikum yang merupakan sarana dan prasarana pokok untuk membekali siswa dalam keterampilan psikomotor untuk setiap keahlian. Sarana dan prasarana laboratorium praktikum SMK Negeri 2 Singaraja harus sesuai dengan standar yang sudah ditentukan. Sering sekali laboratorium praktikum kurang memadai sehingga menghambat proses belajar mengajar dan pencapaian hasil belajar. Hal tersebut mendorong peneliti untuk meneliti tentang kelengkapan saranan dan prasarana praktikum di SMK Negeri 2 Singaraja.

Berdasarkan pemaparan di atas maka dalam penelitian ini mengambil judul tentang "Kontribusi Ekspektasi Karir, Motivasi Berprestasi, Kompetensi Pedagogik Guru, dan Sarana Prasarana Sekolah Terhadap Hasil Belajar Praktikum Siswa Kelas X Jurusan Tata Boga Di 


\section{SMK Negeri 2 Singaraja". \\ METODE PENELITIAN}

Rancangan penelitian yang digunakan dalam penelitian ini adalah rancangan penelitian kuantitatif dengan pendekatan pada subyek penelitian, maka penelitian yang dilakukan ini tergolong penelitian "ex post facto" dalam pelaksanaannya tidak ada perlakuan terhadap variabel, karena kondisi variabel yang diteliti sudah tampak atau sudah berlangsung. Dalam menganalisis data dipergunakan Regresi linier didasarkan pada hubungan fungsional ataupun kausal satu variabel independen dengan satu variabel dependen (Sugiyono, 2010: 261). Data penelitian menyangkut lima variabel terdiri dari satu variabel terikat yaitu hasil belajar praktikum (Y) dengan empat variabel bebas yaitu variabel bebas pertama ekspektasi karir (X1), variabel bebas kedua motivasi berprestasi (X2), variabel bebas ketigakompetensi pedagogik guru (X3), dan variabel bebas keempat sarana prasarana sekolah (X4).

Menurut Agung (2014:69) menyatakan populasi adalah keseluruhan objek dalam suatu penelitian. Sedangkan menurut Sugiyono (1997: 118) menjelaskan populasi adalah wilayah generalisasi yang terdiri atas subyek yang mempunyai kualitas dan karakteristik tertentu yang ditetapkan oleh peneliti untuk dipelajari kemudian ditarik kesimpulannya. Berdasarkan pendapat diatas dapat disimpulkan populasi adalah keseluruhan subyek yang akan diteliti dengan memiliki ciri-ciri sesuai dengan apa yang ditetapkan oleh peneliti. Populasi subyek dalam penelitian ini adalah siswa kelas X Jurusan Tata Boga di SMK Negeri 2 Singaraja yang berjumlah 144 orang.

Sampel merupakan bagian dari populasi yang mewakili seluruh populasi yang digunakan sebagai sumber data dalam penelitian. Berdasarkan tabel Morgan, apabila jumlah populasi sebanyak 144 orang, maka sampel yang bisa diambil adalah 103 orang. Sehingga jumlah sampel dalam penelitian ini adalah 103 orang.

Variabel-variabel yang dimaksud dalam penelitian ini terdiri dari empat variabel bebas (independent), satu variabel terikat (dependent). Variabel-variabel bebas yang diteliti yaitu ada 4, variabel bebas pertama ekspektasi karir (X1), variabel bebas kedua motivasi berprestasi(X2), variabel bebas ketiga kompetensi pedagogik guru (X3), variabel bebas keempatsarana prasarana sekolah (X4), dan variabel terikat adalah hasil belajar (Y).

Pengumpulan data adalah suatu proses pengadaan data primer untuk keperluan penelitian yang digunakan untuk menguji hipotesis yang telah dirumuskan. Untuk memperoleh data mengenai variabel yang diteliti, dalam penelitian ini data dikumpulkan dengan kuesioner mengenai data tentang ekspektasi karir, motivasi berprestasi, kompetensi pedagogik guru, dan sarana prasarana sekolah dan tes untuk hasil belajar siswa. Untuk memperoleh data tersebut digunakan lima buah instrument, yaitu: 1) kuesioner ekspektasi karir, 2) kuesioner motivasi berprestasi, 3) kuesioner kompetensi pedagogik guru, 4) sarana prasarana sekolah dan 5) tes hasil belajar.

Alat pengumpul data harus memenuhi persyaratan yaitu syarat validitas dan reliabilitas dalam mengungkap apa yang hendak diukur. Ada dua persyaratan yang hendak digunakan dalam pengumpulan data penelitian yaitu validitas dan reliabilitas (Hamzah, 2007:63). Validitas instrumen dalam penelitian ini meliputi dua segi yaitu validitas isi dan validitas butir. Validitas isi dibantu oleh dua orang ahli/ expert, kemudian dianalisis dengan teknik Gregory.

Sebelum instrumen digunakan, maka perlu diuji dahulu validitas dari masing-masing pertanyaan yang ada sebagai alat pengambilan data. Dengan demikian terlebih dahulu diadakan uji coba terhadap kuisioner kemudian hasil uji coba ini dianalisis. Untuk menguji validitas butir rumus yang digunakan adalah rumus kontribusi product moment dari Pearson (Arikunto, 1995).

Pengujian terhadap reabilitas instrumen dilakukan melalui pendekatan ketetapan internal. Uji reliabilitas adalah ketepatan dan keajegan alat pengukur tersebut dalam menilai apa yang diinginkan, artinya kapanpun alat tersebut digunakan akan diperoleh hasil yang sama (Puger, 2004). Pengujian reliabilitas dengan rumus Alpha dari Crombach (Arikunto, 1997:164). 
Informasi yang dicari dalam penelitian ini adalah: 1) ekspektasi karir, motivasi berprestasi, kompetensi pedagogik guru, sarana prasarana sekolah serta gambaran umum hasil belajar praktikum siswa kelas X Jurusan Tata Boga di SMK Negeri 2 Singaraja. Gambaran umum tersebut berupa skor rata-rata, simpangan baku, skor terendah, skor tertinggi, modus, dan median, 2) model regresi antara empat variabel bebas dan satu variabel terikat baik sendiri-sendiri maupun bersama-sama, 3) koefisien regresi dari masingmasing model regresi, digunakan untuk meramal atau menaksir besarnya variansi nilai $Y$ (variabel terikat), dan 4) korelasi parsial digunakan untuk menentukan hubungan murni antara satu variabel bebas dengan variabel terikat, dengan mengendalikan variabel bebas lainnya.

Kegiatan analisis data terdiri atas kegiatan pengolahan data dan analisis statistik. Kegiatan analisis data meliputi: 1) menyunting data secara manual. Penyuntingan dilakukan karena kemungkinan ada data yang tidak jelas, atau kesalahan dalam pengisian instrument, sehingga tidak memenuhi syarat untuk dianalisis, 2) mentabulasi data, dan 3) mengolah data dalam bentuk sesuai kebutuhan.

Untuk menguji hipotesis yang telah dirumuskan, terlebih dahulu dilakukan analisis data yang telah dikumpulkan. Dalam melakukan analisis data untuk penelitian ini dilakukan dengan tiga tahapan yakni: 1) tahap deskripsi data, 2) tahap pengujian persyarat analisis, 3) tahap pengujian hipotesis.

Data yang telah diperoleh dari penelitian dideskripsikan menurut masing-masing variabel. Oleh tujuannya seperti itu, maka akan dicari harga rerata (M), standar deviasi (SD), modus (Mo), dan median (Me) setiap variabel yang diteliti.

Setelah data dideskripsikan, maka analisis dilanjutkan dengan menggunakan teknik regresi sederhana, regresi ganda, dan korelasi varsial.Persyaratan yang berkaitan dengan teknik analisis data tersebut harus dibuktikan secara statistik.

Setelah seluruh uji prasyarat terpenuhi, maka dilanjutkan dengan uji hipotesis. Untuk menguji hipotesis pertama, kedua, ketiga dan keempat dalam penelitian ini digunakan teknik analisis korelasi sederhana (korelasi product moment pearson). Sedangkan untuk menguji hipotesis ke empat, digunakan teknik analisis korelasi ganda, regresi ganda, dan korelasi parsial. Untuk menganalisis uji hipotesis dalam penelitian ini digunakan program SPSS17.00 for windows.

\section{HASIL PENELITIAN DAN PEMBAHASAN}

\section{Kontribusi Ekspektasi Karir terhadap Hasil Belajar Praktikum Siswa Kelas $X$ Jurusan Tata Boga di SMK Negeri 2 Singaraja}

Berdasarkan analisis data yang telah dilakukan, Secara normatif ditemukan bahwa ekspektasi karir berada pada kategori sangat baik. Selain itu, hasil analisis juga menunjukkan bahwa terdapat korelasi yang signifikan antara ekspektasi karir dengan hasil belajar Praktikum siswa kelas $X$ Jurusan Tata Boga di SMK Negeri 2 Singaraja melalui persamaan garis regresi $\hat{y}=29,673+0,414$.X1 dengan Freg $=140,854(p<0,05)$. Sedangkan korelasi yang signifikan terjadi antara ekspektasi karir dengan hasil belajar Praktikum sebesar 0,763 dengan $p<0,05$ dan variabel ekspektasi karir dapat menjelaskan hasil belajar Praktikum siswa kelas X Jurusan Tata Boga di SMK Negeri 2 Singaraja sebesar 58,2\%. Temuan ini mengindikasikan bahwa ekspektasi karir mempunyai peranan penting dalam meningkatkan hasil belajar Praktikum siswa kelas X Jurusan Tata Boga di SMK Negeri 2 Singaraja. Sumbangan efektif (SE) variabel ekspektasi karir terhadap hasil belajar Praktikum siswa kelas X Jurusan Tata Boga di SMK Negeri 2 Singaraja adalah sebesar 36,42\%.

Temuan dalam penelitian ini sejalan dengan temuan penelitian yang dilakukan oleh Priyanti (2014) yang berjudul "Kontribusi Informasi Karir, Bimbingan Karir dan Ekspektasi Karir Terhadap Kompetensi Lulusan SMALB Di SLB B Negeri Pembina Tingkat Nasional Jimbaran". Hasil analisis data menunjukkan: 1) Terdapat kontribusi positif dan signifikan antara informasi karir terhadap kompetensi lulusan SMALB sebesar 1,51\%. 2) Terdapat kontribusi positif dan signifikan antara bimbingan karir terhadap kompetensi lulusan SMALB 
sebesar 22,18\%. 3) Terdapat kontribusi positif dan signifikan antara ekspektasi karir terhadap kompetensi lulusan SMALB sebesar 43,83\%. 4) Secara bersama-sama terdapat kontribusi positif dan signifikan antara informasi karir, bimbingan karir dan ekspektasi karir terhadap kompetensi lulusan sebesar 20,16\% dengan sumbangan efektif masing-masing X1 55.604, X2 38.474, X3 74.580. 5) Penelitian juga membuktikan bahwa berdasarkan besarnya korelasi parsial, ternyata kontribusi ekspektasi karir menduduki peringkat pertama dengan koefisien kontribusi $43,83 \%$, dan bimbingan karir terhadap kompetensi lulusan menduduki peringkat ke dua dengan kontribusi $22,18 \%$, dan informasi karir menduduki peringkat ketiga dengan koefisien kontribusi 20,16.

Jika seseorang melakukan suatu kegiatan tanpa mengetahui tujuan kegiatannya, tentu kurang semangat. Begitu pula seorang siswa mengikuti pelajaran tertentu, tetapi dia tidak tahu tujuannya, jelas akan kurang semangat. Apabila seorang siswa sudah mengetahui secara pasti profesi-profesi yang mungkin dapat diperoleh dengan modal bisa berkomunikasi dengan kompetensi, tentu saja akan dapat membangkitkan semangatnya untuk mempelajari materi pembelajaran tersebut. Pengetahuan mengenai ekspektasi karier yang berkaitan dengan kemampuan yang dimiliki oleh siswa, tentu akan memberikan semangat belajar bagi siswa sehingga mampu meningkatkan hasil belajar siswa.

Dengan melihat tuntutan dari suatu karir muncullah tanggapan berdasarkan apa yang ada dalam diri individu yang bersangkutan, seperti keadaan fisik, kemampuan, minat dan bakat. Latar belakang tanggapan tersebut adalah nilai-nilai yang ada dalam dirinya, seperti: gaya hidup, tujuan hidup, dan harapan-harapan masa depannya, sehingga setiap individu memiliki persepsi yang berbeda-beda terhadap suatu karir. Selanjutnya nanti dalam pemilihan karir atau perencanaan masa depannya akan disesuaikan dengan persepsinya, pernyataan ini digunakan sebagai dimensi pertama dari kisi-kisi angket ekspektasi karier.

Pengetahuan tentang seluk-beluk suatu profesi akan memberikan harapan bagi setiap orang yang berminat terhadap profesi tersebut. Harapan inilah yang disebut dengan ekspektasi karier. Dengan munculnya harapan, maka akan timbul semangat untuk mempelajari hal-hal yang berkaitan dengan profesi tersebut. Semangat yang mekar dapat menjadi daya dorong yang kuat guna membangkitkan motivasi belajar.

Dari uraian tersebut diduga terdapat hubungan yang saling berkaitan antar hasil belajar dengan ekspektasi karier. Berdasarkan hal tersebut maka dapat diketahui terdapat kontribusi ekspektasi karier terhadap hasil belajar siswa.Berdasarkan pemaparan di atas, maka dapat disimpulkan bahwa ekspektasi karir memberikan kontribusi yang signifikan terhadap hasil belajar Praktikum pada siswa kelas X Jurusan Tata Boga di SMK Negeri 2 Singaraja.

\section{Kontribusi Motivasi Berprestasi terhadap Hasil Belajar Praktikum Siswa Kelas $\mathbf{X}$ Jurusan Tata Boga di SMK Negeri 2 Singaraja}

Berdasarkan analisis data yang telah dilakukan, secara normatif ditemukan bahwa motivasi berprestasi berada pada kategori sangat baik. Selain itu, hasil analisis juga menunjukkan bahwa terdapat korelasi yang signifikan antara motivasi berprestasi dengan siswa kelas $X$ Jurusan Tata Boga di SMK Negeri 2 Singaraja melalui persamaan garis regresi $\hat{y}=56,856+0,224 X 2$ dengan Freg $=29,379(p<0,05)$. Sedangkan korelasi yang signifikan terjadi antara motivasi berprestasi dengan hasil belajar Praktikum sebesar 0,475 dengan $p<0,05$ dan variabel motivasi berprestasi dapat menjelaskan siswa kelas $X$ Jurusan Tata Boga di SMK Negeri 2 Singaraja sebesar 21,8\%. Temuan ini mengindikasikan bahwa motivasi berprestasi mempunyai peranan penting dalam meningkatkan hasil belajar Praktikum siswa kelas X Jurusan Tata Boga di SMK Negeri 2 Singaraja. Sumbangan efektif (SE) variabel ekspektasi karir kepala sekolah terhadap hasil belajar Praktikum siswa kelas $\mathrm{X}$ Jurusan Tata Boga di SMK Negeri 2 Singaraja adalah sebesar 5,97\%.

Temuan dalam penelitian ini sejalan dengan temuan penelitian yang dilakukan oleh Suniadi (2013) yang berjudul "Analisis Kontribusi Disiplin Belajar, Ekspektasi Karir, dan Motivasi Berprestasi Terhadap Prestasi Belajar Bahasa Inggris Siswa SMP Kelas VIII SMP Negeri 3 Kediri”. Hasil penelitian menunjukkan bahwa: (1) terdapat kontribusi disiplin belajar 
terhadap prestasi belajar bahasa Inggris siswa kelas VIII se-kecamatan Kediri dengan kontribusi sebesar 39,1\%, (2) terdapat kontribusi ekspektasi karir terhadap prestasi belajar bahasa Inggris siswa kelas VIII se-kecamatan Kediri dengan kontribusi sebesar 26,3\%, (3) kontribusi motivasi berprestasi terhadap prestasi belajar bahasa Inggris siswa kelas VIII sekecamatan Kediri dengan kontribusi sebesar 31,8\%, dan (4) terdapat kontribusi disiplin belajar, ekspektasi karir, dan motivasi berprestasi terhadap prestasi belajar bahasa Inggris siswa kelas VIII se-kecamatan Kediri dengan kontribusi sebesar 50,1\%. Berdasarkan temuan penelitian ini disimpulkan bahwa terdapat kontribusi disiplin belajar, ekspektasi karir, dan motivasi berprestasi terhadap prestasi belajar bahasa Inggris siswa kelas VIII sekecamatan Kediri.

Motivasi dapat diartikan kemauan/pendorong atau penarik seseorang untuk mau melaksanakan tugasnya dengan sebaik-baiknya. Motivasi merupakan suatu bentuk reaksi terhadap kebutuhan manusia yang menimbulkan eksistensi dalam diri manusia yaitu keinginan terhadap sesuatu yang belum terpenuhi dalam hidupnya sehingga terdorong untuk melakukan tindakan guna memenuhi dan memuaskan keinginannya. Motivasi berprestasi tidak lain adalah motivasi yang dimiliki oleh siswa untuk selalu berprestasi dibidang akademik atau bisa didefinisikan sebagai unsur yang membangkitkan, mengarahkan, dan mendorong seorang siswa untuk melakukan tindakan dan mengatasi segala tantangan dan hambatan dalam upaya untuk mencapai hasil belajar yang lebih baik.

Jika seseorang melakukan suatu kegiatan dengan motivasi berprestasi yang tinggi maka dapat membangkitkan semangatnya untuk mempelajari pembelajaran tersebut sehingga mampu meningkatkan hasil belajar. Oleh sebab itu, guru harus mampu meningkatkan motivasi berprestasi siswa agar siswa tersebut memiliki keinginan untuk belajar lebih giat lagi, berdasarkan hal tersebut maka terdapat kontribusi motivasi berprestasi terhadap hasil belajar siswa.

Berdasarkan pemaparan di atas, maka dapat disimpulkan bahwa motivasi berprestasi memberikan kontribusi yang signifikan terhadap hasil belajar Praktikum pada siswa kelas $\mathrm{X}$ Jurusan Tata Boga di SMK Negeri 2 Singaraja.

\section{Kontribusi Kompetensi Pedagogik Guru terhadap Hasil Belajar Praktikum Siswa Kelas X Jurusan Tata Boga di SMK Negeri 2 Singaraja}

Berdasarkan analisis data yang telah dilakukan, secara normatif ditemukan bahwa kompetensi pedagogik berada pada kategori sangat baik. Selain itu, hasil analisis juga menunjukkan bahwa terdapat korelasi yang signifikan antara kompetensi pedagogik dengan hasil belajar Praktikum siswa kelas X Jurusan Tata Boga di SMK Negeri 2 Singaraja melalui persamaan garis regresi $\hat{y}=43,813+0,263 \times 3$ dengan Freg $=82,980(p<0,05)$. Sedangkan korelasi yang signifikan terjadi antara kompetensi pedagogik dengan hasil belajar Praktikum sebesar 0,672 dengan $p<0,05$ dan variabel kompetensi pedagogik dapat menjelaskan hasil belajar Praktikum siswa kelas X Jurusan Tata Boga di SMK Negeri 2 Singaraja sebesar $45,1 \%$. Temuan ini mengindikasikan bahwa kompetensi pedagogik mempunyai peranan penting dalam meningkatkan hasil belajar Praktikum siswa kelas $X$ Jurusan Tata Boga di SMK Negeri 2 Singaraja. Sumbangan efektif (SE) variabel kompetensi pedagogik terhadap hasil belajar Praktikum siswa kelas X Jurusan Tata Boga di SMK Negeri 2 Singaraja adalah sebesar $19,38 \%$.

Hasil penelitian ini sejalan dengan hasil penelitian yang dilakukan oleh Kusuma (2013), dengan judul "Kontribusi Persepsi Siswa Tentang Kemampuan Guru Mengelola Pembelajaran, Kemampuan Verbal, dan Ekspektasi Karir Terhadap Prestasi Belajar Bahasa Inggris Siswa IPA pada SMA Negeri Di Kecamatan Tabanan". Hasil penelitian menunjukkan bahwa (1) terdapat kontribusi yang positif dan signifikan persepsi siswa tentang kemampuan guru mengelola pembelajaran terhadap prestasi belajar bahasa Inggris siswa sebesar $6 \%$ dengan sumbangan efektif sebesar $2,77 \%$, (2) terdapat kontribusi yang positif dan signifikan kemampuan verbal terhadap prestasi belajar bahasa Inggris siswa sebesar $83 \%$ dengan sumbangan efektif sebesar 38,35\%, (3) terdapat kontribusi yang positif dan signifikan 
ekspektasi karir terhadap prestasi belajar bahasa Inggris siswa sebesar $11 \%$ dengan sumbangan efektif sebesar 5,08\%, (4) terdapat kontribusi yang positif dan signifikan secara bersama-sama persepsi siswa tentang kemampuan guru mengelola pembelajaran, kemampuan verbal, dan ekspektasi karir terhadap prestasi belajar bahasa Inggris siswa IPA pada SMA Negeri di Kecamatan Tabanan sebesar 46,2\%.

Kompetensi pedagogik merupakan suatu performansi (kemampuan) seseorang dalam bidang ilmu pendidikan. Untuk menjadi guru yang profesional haruslah memiliki kompetensi padagogik. Dalam Standar Nasional Pendidikan, penjelasan Pasal 28 ayat (3) butir a mengemukakan bahwa kompetensi pedagogik adalah kemampuan mengelola pembelajaran peserta didik yang meliputi pemahaman terhadap peserta didik, perancangan dan pelaksanaan pembelajaran, evaluasi hasil belajar, dan pengembangan peserta didik untuk mengaktualisasikan berbagai potensi yang dimilikinya. Kompetensi pedagogik adalah kemampuan guru dalam mengelola pembelajaran peserta didik, meliputi: menyiapkan perangkat pembelajaran, melaksanakan pembelajaran, dan evaluasi pembelajaran.

Berdasarkan definisi tesebut diatas, maka dapat disimpulkan kompetensi pedagogik adalah kemampuan yang dimiliki oleh seorang guru dalam memahami peserta didiknya dan kemampuan dalam melaksanakan proses pembelajaran, mulai dari perencanaan, pelaksanaan dan evaluasi. Jika setiap guru memiliki kompetensi pedagogik yang tinggi, maka dapat mempengaruhi proses pembelajaran yang terjadi di sekolah, sehingga berdampak positif terhadap hasil belajar siswa.

Dari uraian tersebut diduga terdapat hubungan yang saling berkaitan antar kompetensi pedagogik guru dengan hasil belajar siswa. Berdasarkan hal tersebut maka dapat diketahui terdapat kontribusikompetensi pedagogik guru terhadap hasil belajar siswa. Berdasarkan pemaparan di atas, maka dapat disimpulkan bahwa kompetensi pedagogik memberikan kontribusi yang signifikan terhadap hasil belajar Praktikum pada siswa kelas X Jurusan Tata Boga di SMK Negeri 2 Singaraja.

\section{Kontribusi Sarana Prasarana terhadap Hasil Belajar Praktikum Siswa Kelas X Jurusan Tata Boga di SMK Negeri 2 Singaraja}

Berdasarkan analisis data yang telah dilakukan, secara normatif ditemukan bahwa sarana prasarana sekolah berada pada kategori sangat baik. Selain itu, hasil analisis juga menunjukkan bahwa terdapat korelasi yang signifikan antara sarana prasarana sekolah dengan hasil belajar Praktikum siswa kelas X Jurusan Tata Boga di SMK Negeri 2 Singaraja melalui persamaan garis regresi $\hat{y}=50,942+0,224 X 4$ dengan Freg $=79,025(p<0,05)$. Sedangkan korelasi yang signifikan terjadi antara sarana prasarana sekolah dengan hasil belajar Praktikum sebesar 0,663 dengan $\mathrm{p}<0,05$ dan variabel kompetensi pedagogik dapat menjelaskan hasil belajar Praktikum siswa kelas X Jurusan Tata Boga di SMK Negeri 2 Singaraja sebesar $43,9 \%$. Temuan ini mengindikasikan bahwa sarana prasarana sekolah mempunyai peranan penting dalam meningkatkan hasil belajar Praktikum siswa kelas $X$ Jurusan Tata Boga di SMK Negeri 2 Singaraja. Sumbangan efektif (SE) variabel sarana prasarana sekolah terhadap hasil belajar Praktikum siswa kelas X Jurusan Tata Boga di SMK Negeri 2 Singaraja adalah sebesar 10,39\%.

Sarana prasarana merupakan sarana penunjang bagi proses belajar-mengajar atau semua fasilitas yang diperlukan dalam proses belajar mengajar, baik yang bergerak maupun yang tidak bergerak agar pencapaian tujuan pendidikan berjalan dengan lancar, teratur, efektif, dan efisien.

Ditinjau dari fungsi atau peranannya terhadap pelaksanaan proses belajar mengajar, sarana pendidikan (sarana material) dibedakan menjadi 3 macam, yakni (1) Alat pelajaran; (2) Alat peraga; (3) Media pengajaran. Prasarana ini juga berperan dalam proses belajar mengajar walaupun secara tidak langsung. Kadang-kadang pengertian tentang alat pelajaran, alat peraga, dan media pendidikan masih sukar dibedakan orang. Alat pelajaran adalah alat yang digunakan secara langsung dalam proses belajar mengajar. Alat ini mungkin berwujud buku, alat peraga, alat tulis, dan alat praktik. Sedangkan pengertian alat 
peraga adalah alat pembantu pendidikan dan pengajaran, dapat berupa perbuatanperbuatan atau benda-benda yang sudah memberi pengertian kepada anak didik berturutturut dari yang abstrak sampai kepada yang konkret. Sedangkan media pengajaran adalah sarana pengajaran yang digunakan sebagai perantara dalam proses belajar mengajar, untuk lebih mempertinggi efektivitas dan efisiensi dalam mencapai tujuan pendidikan.

Berdasarkan pemaparan di atas, dengan adanya sarana prasarana yang lengkap tentunya akan sangat membantu guru dan siswa dalam menjalankan proses pembelajaran. Terbantunya guru dan siswa dalam proses pembelajaran tentunya akan mempengaruhi hasil belajar siswa dalam proses pembelajaran. Sehingga dapat diduga bahwa semakin baik sarana prasarana yang dimiliki sekolah, semakin baik pula hasil belajar siswa, khususnya hasil belajar praktikum siswa.

\section{Kontribusi Ekspektasi Karir, Motivasi Berprestasi, Kompetensi Pedagogik Guru, dan Sarana Prasarana Sekolah terhadap Hasil Belajar Praktikum Siswa Kelas X Jurusan Tata Boga di SMK Negeri 2 Singaraja}

Berdasarkan analisis yang telah dilakukan, ditemukan bahwa terdapat korelasi yang signifikan secara bersama-sama antara ekspektasi karir kepala sekolah, motivasi berprestasi, kompetensi pedagogik, dan sarana prasarana sekolah terhadap hasil belajar Praktikum melalui persamaan garis regresi $\hat{y}=16,076+0,259 X 1+0,059 X 2+0,113 X 3+$ $0,053 \times 4$ dengan Freg $=63,486(p<0,05)$. Ini berarti terdapat hubungan secara bersamasama antara ekspektasi karir, motivasi berprestasi, kompetensi pedagogik, dan sarana prasarana sekolah terhadap hasil belajar Praktikum siswa kelas $X$ Jurusan Tata Boga di SMK Negeri 2 Singaraja. Hal ini mengindikasikan bahwa makin baik ekspektasi karir, motivasi berprestasi, kompetensi pedagogik, dan sarana prasarana sekolah makin baik pula hasil belajar Praktikum tersebut.

Hasil belajar siswa dipengaruhi oleh banyak faktor. Faktor tersebut meliputi faktor internal (siswa), salah satunya mengenai karir, motivasi belajar siswa dan faktor eksternal yakni kompetensi yang dimiliki oleh guru. Kesesuaian antara proses pembelajaran dengan ekspektasi karir di masa depan sangat mempengaruhi hasil belajar siswa, siswa akan lebih termotivasi dalam proses pemebelajaran. Selain itu, pebelajaran yang diterapkan oleh guru sangat berpengaruh terhadap hasil belajarnya. Apabila desain pembelajaran yang diterapkan tidak sesuai dengan kemampuan siswa, maka hasil belajarnya pun diduga rendah, begitu pula sebaliknya.

Siswa yang memiliki motivasi berprestasi yang tinggi cenderung aktif dalam kegiatan pembelajaran. Hal ini sangat sesuai dengan kegiatan pembelajaran yang mengupayakan agar siswa lebih aktif dalam proses pembelajaran. Hasil belajar di bidang pendidikan adalah hasil dari pengukuran terhadap peserta didik yang meliputi faktor kognitif, afektif dan psikomotor setelah mengikuti proses pembelajaran yang diukur dengan menggunakan instrumen tes atau instrumen yang relevan. Dengan demikian, hasil belajar merupakan hasil dari proses belajar yang menyangkut afektif, kognitif, dan psikomotor.

Seperti yang sudah dijelaskan di atas bahwa untuk dapat menghasilkan anak-anak yang berprestasi dan dapat bersaing dalam persaingan dimasa depan seharusnya dimulai dari peningkatan ekspektasi karier, motivasi berprestasi, kompetensi pedagogik guru dan sarana prasarana sekolah. Semua ini tidak lepas dari guru pengajar. Hal ini berarti bahwa keempat variabel bebas dalam penelitian ini saling memberikan kontribusi terhadap peningkatan hasil belajar siswa.Hasil belajar yang tinggi tidak dapat ditentukan oleh satu faktor saja misalnya hanya bakat tetapi faktor lain seperti motivasi dan ekspektasi karier adalah faktor yang tidak dapat diabaikan, serta faktor sarana prasarana yang menjadi faktor pendukung dari proses belajar mengajar. Berdasarkan hal tersebut maka diduga terdapat kontribusiekspektasi karir, motivasi berprestasi, kompetensi pedagogik guru, dan sarana prasarana sekolah terhadap hasil belajar praktikum siswa

Korelasi murni antara ekspektasi karir, motivasi berprestasi, kompetensi pedagogik, dan sarana prasarana sekolah dengan hasil belajar Praktikum siswa kelas X Jurusan Tata 
Boga di SMK Negeri 2 Singaraja yang diperoleh melalui analisis korelasi parsial jenjang kedua. Hasil yang diperoleh adalah: pertama, terdapat korelasi yang signifikan antara variabel ekspektasi karir terhadap hasil belajar Praktikum dengan dikendalikan oleh variabel motivasi berprestasi, kompetensi pedagogik, dan sarana prasarana sekolah $\left(r_{1 y-234}=0,763\right)$ dengan $\mathrm{p}<0,05)$. Ini menunjukkan bahwa ekspektasi karir memberikan kontribusi yang signifikan terhadap hasil belajar Praktikum siswa kelas $X$ Jurusan Tata Boga di SMK Negeri 2 Singaraja, sehingga dapat dijadikan prediktor kecenderungan tingkat hasil belajar Praktikum siswa kelas X Jurusan Tata Boga di SMK Negeri 2 Singaraja.

Kedua, terdapat korelasi yang signifikan motivasi berprestasi terhadap hasil belajar Praktikum dengan dikendalikan oleh variabel ekspektasi karir, kompetensi pedagogik, dan sarana prasarana sekolah $\left(r_{2 y-134}=0,475\right.$ dengan $\left.p>0,05\right)$. Ini menunjukkan bahwa motivasi berprestasi memberikan kontribusi terhadap hasil belajar Praktikum siswa kelas $X$ Jurusan Tata Boga di SMK Negeri 2 Singaraja, sehingga dapat dijadikan prediktor kecenderungan tingkat hasil belajar Praktikum siswa kelas $\mathrm{X}$ Jurusan Tata Boga di SMK Negeri 2 Singaraja.

Ketiga, terdapat korelasi yang signifikan antara kompetensi pedagogik terhadap hasil belajar Praktikum dengan dikendalikan oleh variabel ekspektasi karir, motivasi berprestasi, dan sarana prasarana sekolah $\left(r_{3 y-124}=0,672\right.$ dengan $\left.p>0,05\right)$. Ini menunjukkan bahwa kompetensi pedagogik memberikan kontribusi terhadap hasil belajar Praktikum siswa kelas $X$ Jurusan Tata Boga di SMK Negeri 2 Singaraja, sehingga dapat dijadikan prediktor kecenderungan tingkat hasil belajar Praktikum siswa kelas X Jurusan Tata Boga di SMK Negeri 2 Singaraja.

Keempat, terdapat korelasi yang signifikan antara sarana prasarana sekolah terhadap hasil belajar Praktikum dengan dikendalikan oleh variabel ekspektasi karir, motivasi berprestasi dan kompetensi pedagogik $\left(r_{4 y-123}=0,663\right.$ dengan $\left.p>0,05\right)$. Ini menunjukkan bahwa sarana prasarana sekolah memberikan kontribusi terhadap hasil belajar Praktikum siswa kelas $X$ Jurusan Tata Boga di SMK Negeri 2 Singaraja, sehingga dapat dijadikan prediktor kecenderungan tingkat hasil belajar Praktikum siswa kelas X Jurusan Tata Boga di SMK Negeri 2 Singaraja.

Kekuatan hubungan keempat variabel bebas dengan hasil belajar Praktikum siswa kelas X Jurusan Tata Boga di SMK Negeri 2 Singaraja secara berurutan adalah: ekspektasi karir, motivasi berprestasi, kompetensi pedagogik, dan sarana prasarana sekolah mempunyai kontribusi terhadap hasil belajar Praktikum.

\section{PENUTUP}

Berdasarkan hasil penelitian dan pembahasan yang telah dilakukan, maka dapat ditarik kesimpulan sebagai berikut.

Pertama, terdapat kontribusi yang signifikan ekspektasi karir terhadap hasil belajar Praktikum pada siswa kelas X Jurusan Tata Boga di SMK Negeri 2 Singaraja dengan koefisien korelasi sebesar 0,763 dan sumbangan efektifnya sebesar 36,42\%.

Kedua, terdapat kontribusi yang signifikan motivasi berprestasi terhadap hasil belajar Praktikum pada siswa kelas X Jurusan Tata Boga di SMK Negeri 2 Singaraja. dengan koefisien korelasi sebesar 0,475 dan sumbangan efektifnya sebesar 5,97\%.

Ketiga, terdapat kontribusi yang signifikan kompetensi pedagogik terhadap hasil belajar Praktikum pada siswa kelas X Jurusan Tata Boga di SMK Negeri 2 Singaraja dengan koefisien korelasi sebesar 0,672 dan sumbangan efektifnya sebesar 19,38\%.

Keempat, terdapat kontribusi yang signifikan sarana prasarana sekolah terhadap hasil belajar Praktikum pada siswa kelas X Jurusan Tata Boga di SMK Negeri 2 Singaraja dengan koefisien korelasi sebesar 0,663 dan sumbangan efektifnya sebesar 10,39\%.

Kelima, secara bersama-sama, ada kontribusi yang signifikan ekspektasi karir, motivasi berprestasi, kompetensi pedagogik, dan sarana prasarana sekolah terhadap hasil belajar Praktikum pada siswa kelas X Jurusan Tata Boga di SMK Negeri 2 Singaraja dengan 
koefisien korelasi ganda sebesar 0,849 dan kontribusinya sebesar 72,2\% terhadap hasil belajar Praktikum siswa kelas X Jurusan Tata Boga di SMK Negeri 2 Singaraja.

Saran yang dapat diajukan pada penelitian ini adalah sebagai berikut.

Siswa disarankan dapat meningkatkan ekspektasi karir dan motivasi berprestasinya agar dapat meningkatkan hasil belajar mereka.

Guru hendaknya mampu untuk meningkatkan kompetensi pedagogik yang dimiliki. Hal ini bertujuan agar proses pembelajaran yang ada di sekolah dapat berjalan dan dikelola secara optimal, sehingga dapat berkontribusi positif terhadap hasil belajar siswa.

Peneliti lain diharapkan mampu mengembangkan variabel lain dalam usaha meningkatkan hasil belajar Praktikum, sehingga dapat mengembangkan ilmu pengetahuan ke arah yang lebih baik.

\section{DAFTAR RUJUKAN}

Agung, Anak Agung Gede. 2014. Metodologi Penelitian Pendidikan. Malang: Aditya Media Publishing.

Arikunto, Suharsimi. 1995. Manajemen Penelitian. Jakarta: Rineka Cipta.

Arikunto, Suharsimi. 1997. Prosedur Penelitian Suatu Pendekatan Praktek. Jakarta: Rineka Cipta.

Hamzah, B. Uno. 2007. Teori Motivasi dan Pengukurannya. Jakarta: Bumi Aksana.

Irmayanti Kusuma, Luh Putu Susy. 2013. Kontribusi Persepsi Siswa Tentang Kemampuan Guru Mengelola Pembelajaran, Kemampuan Verbal, dan Ekspektasi Karir Terhadap Prestasi Belajar Bahasa Inggris Siswa IPA pada SMA Negeri Di Kecamatan Tabanan. e-Journal Program Pascasarjana Universitas Pendidikan Ganesha. Program Studi Administrasi Pendidikan (Volume 4 Tahun 2013).

Priyanti, Dede. 2014. Kontribusi Informasi Karir, Bimbingan Karir dan Ekspektasi Karir Terhadap Kompetensi Lulusan SMALB Di SLB.B Negeri Pembina Tingkat Nasional Jimbaran. e-Journal Program Pascasarjana Universitas Pendidikan Ganesha. Program Studi Administrasi Pendidikan (Volume 5 Tahun 2014).

Puger, I Gusti Ngurah. 2004. Belajar Kooperatif. Diktat Perkuliahan Mahasiswa Unipas.

Sugiyono. 2010. Metode Penelitian Administrasi: Pendekatan Kuantitatif, Kualitatif, dan $R \& D$.Bandung: Alfabeta.

Sugiyono. 1997. Statistika II. Bandung: Transito

Suniadi, Ni Nyoman Ayu. 2013. Analisis Kontribusi Disiplin Belajar, Ekspektasi Karir, dan Motivasi Berprestasi Terhadap Prestasi Belajar Bahasa Inggris Siswa SMP Kelas VIII SMP Negeri 3 Kediri. e-Journal Program Pascasarjana Universitas Pendidikan Ganesha. Program Studi Administrasi Pendidikan (Volume 4 Tahun 2013). 